Original Paper http://ajol.info/index.php/ijbcs http://indexmedicus.afro.who.int

\title{
Assessment of the faecal sludge management practices in households of a sub- Saharan Africa urban area and the health risks associated: the case study of Yaoundé, Cameroon
}

\author{
Wilfried Arsène LETAH NZOUEBET ${ }^{1}$, Ebenezer SOH KENGNE ${ }^{1}$, \\ Guy Valerie DJUMYOM WAFO ${ }^{1}$, Chistian WANDA ${ }^{1}$, Andrea RECHENBURG $^{2}$ and \\ Ives Magloire KENGNE NOUMSI ${ }^{1 *}$ \\ ${ }^{1}$ University of Yaounde I, Faculty of Science, Wastewater Research Unit, B.P. 812 Yaounde, Cameroon. \\ ${ }^{2}$ GeoHealth Centre, Institute for Hygiene and Public Health, University of Bonn, Sigmund Freud Str. 25, D. \\ 53105 Bonn, Germany. \\ *Corresponding author; E-mail: ives_kengne@yahoo.fr
}

\begin{abstract}
The aim of this study was to assess on-site sanitation facilities in Yaounde on the basis of the eight proposed indicators of hygienic safety, sustainability and functionality of the Millennium Development Goals (MDG) target 7 definitions of improve sanitation. Information were collected on the design of toilet facilities, management and functionality through a semi-structured interview and observations of 602 randomly selected toilet facilities in 22 different urban settlements of Yaounde. In addition, information about education and socioeconomic status of householders, management and functionality of toilet facilities and health status of the users were collected. The results revealed several methods of excreta disposal and noted that approximately $3 \%$ of households had no latrine and practiced open defecation. It also showed that $79 \%$ of latrines were covered at the top with concrete slabs while $69 \%$ with ground lined below floors. Households that lacked proper toilet facilities frequently suffered from orally transmitted sanitation-related diseases, with higher prevalence recorded in rainy seasons. This study recommends improvement in the management of sanitation facilities in some settlements of Yaounde in order to guarantee adequate sanitation in a healthy environment.
\end{abstract}

() 2019 International Formulae Group. All rights reserved

Keywords: Excreta disposal facility, waste management, improved sanitation technologies, health consideration, Millennium Development Goals, tropical urban area.

\section{INTRODUCTION}

The purpose of a sanitation system is to protect and promote human health and environmental conditions (Stenström et al., 2011, Koné et al., 2016; Joshua et al., 2017;
Cheng et al., 2018). Provision of adequate sanitation facilities is a basic underlying factor for good human health, economic development and well-being (Verbyla et al., 2013; Tilley et al., 2014; Brown et al., 2015). 
In developing countries, urban areas are estimated to have higher sanitation coverage than rural areas (Carlton et al., 2012), but statistics had often not come out clearly to show the severity and complexity of sanitation challenges affecting towns and the urban poor. It was estimated that in 2010, 2.6 billion individuals did not have access to improve sanitation (Strande et al., 2014). The Sustainable Development Goals (SDGs) adopted by the UN General Assembly in 2015 aims to substantially improve water and sanitation globally, and includes two specific targets within Goal 6 for drinking water, sanitation and hygiene (WaSH): (i) the first target aims at achieving universal and equitable access to safe and affordable drinking water for all by 2030, while the second aims at achieving access to adequate, equitable sanitation and hygiene for all and end open defecation within the same period. Progress towards the Millennium Development Goals (MDGs) which preceded the SDGs was monitored globally based on the use of improved drinking water supplies and sanitation facilities. The SDGs aim at higher water and sanitation service provision and are being monitored using indicators which include elements of service quality that were not captured by the MDG indicators (Wolf et al., 2018).

The generalized approach to define sanitation access for a single household is to assess the use of an 'improved' toilet technology (Jenkins et al., 2014), which may be less appropriate for rapidly growing cities where on-site sanitation technologies, such as pit latrines and septic tanks, are still used, despite the urban population growth. In such situations, sanitation facilities are likely to be emptied rather than moved (Tilley et al., 2014). Hence the safety of sanitation systems depends on safe faecal sludge capture and containment (i.e. the design of the facility),provisions for safe faecal sludge management, including emptying, removal, treatment and disposal, or reuse (Taweesan et al., 2015). In low-and middle-income countries, over $70 \%$ of urban dwellers use mainly on-site sanitation systems such as unsewered latrines and septic tanks for excreta and wastewater disposal (Klingel et al., 2002; Dodane et al., 2012; Ngoutane Pare et al., 2012). Faecal sludge contains extremely high pathogen concentrations, responsible for the elevated endemic rate of excreta-related diseases, especially among children (Faechem et al., 1983; Stenström et al., 2011). In areas where access to sustainable sanitation, (i.e. where safe storage, collection, treatment and safe disposal/reuse of faeces and urine) is inadequate or poor, parasites spread in the natural environment (Tilley at al., 2014; Soh Kengne et al., 2014). Most cities in low- and middle-income countries, which can be categorized as "latrine-based cities", rely on such infrastructure for excreta disposal (Jeuland et al., 2004). Ongoing latrine provision programs, aiming at achieving the SDGs sanitation target, still lack service provision arrangements for collection/emptying, haulage, safe disposal, reuse or treatment of faecal sludge produced by on-site sanitation infrastructures. At any given time, approximately half of the urban populations in Africa suffer from diseases associated with poor sanitation, hygiene and water (De Silva et al., 2011; Aryal et al., 2012; Pujari et al. 2012; Niwagaba et al., 2014; Guiteras et al., 2015). Systematic reviews suggest that improved sanitation can significantly reduce rates of diarrhoeal diseases (Pujari et al., 2012). On-site sanitation systems for excreta collection are widespread in Yaounde, with the predominance of pit latrines (>59\%) (Kengne et al., 2009). The city does not have any faecal sludge treatment plant and it was estimated by Berteigne (2012) that about 700-1,300 $\mathrm{m}^{3}$ of faecal sludge is discharged weekly into the environment of peri-urban areas. This amount has constantly increased due to population increase of the city particularly in urban slums.

This paper presents a detailed assessment of household excreta disposal facilities in some settlements of Yaounde, the capital city of Cameroon. This paper proposes and applies a set of indicators to characterize and assess the hygienic safety and sustained 
functionality of existing latrines, including locally available pit emptying services and disposal methods, based on household survey data. It also assesses the health risks associated with the current sanitation technologies that make up the investigated excreta disposal.

\section{MATERIELS AND METHODS \\ Study area}

This study was carried out in the city of Yaounde (Cameroon). Yaounde is an urban area of approximately $256 \mathrm{~km}^{2}$ and is located between about 700-800 $\mathrm{m}$ above sea level. The town had an estimated population of 2,4 million inhabitants in 2011(BUCREP, 2012). The City faces overpopulation like many other urban cities in developing countries with a density of 14,000 inhabitants $/ \mathrm{km}^{2}$. Parrot et al. (2009) mentioned that more than half $(51 \%)$ of the capital consists of slums with no pipeborne water supply and no centralized sanitation and waste disposal infrastructure. The population has to rely mainly on shallow dug wells and springs for drinking water sources (Graf et al., 2010).

Yaounde has an equatorial climate with four seasons comprising two dry seasons (December-February, July- August) and two rainy seasons (March-June, SeptemberNovember). The average annual rainfall is $1,600 \mathrm{~mm}$ with an average temperature of 23 ${ }^{\circ} \mathrm{C}$ (Lienou et al., 2008). On-site sanitation systems for excreta collection are widespread with the predominance of pit latrines (> 59\%). The city has no FS treatment station and it was estimated that about 700 to $1,300 \mathrm{~m}^{3}$ of FS are discharged weekly into the environment of peri-urban areas (Berteigne, 2012).

\section{Assessment of the existing faecal sludge management practices at household level}

To assess the faecal sludge management practices in households, a heterogeneous stratified sampling method was applied in different urban settlements previously identified in the study area. Therefore, a total of 22 settlements were selectively chosen in the study area according to the heterogeneity of urban settlements of Yaounde and represented by peri-urban interfaces, planned urban area, informal settlements, middle and high income areas according to the methodology described by Lüthi and Parkinson (2011). For these authors, every city is a patchwork of different domains and physical environments, each of which presents their own challenges and opportunities. The distribution of the quarters investigated is shown in Table 1.

The size " $n$ " of the households investigated as a function of the total population "N" was estimated using the margin of error formula for defined population (Barlett et al., 2001):

$$
n=\frac{N}{1+N e^{2}}
$$

With "N" the size of the total population of Yaounde (estimated at about 2.4 million inhabitants (BUCREP, 2012), " $\mathrm{n}$ " the sample size, "e" the marginal error set to $5 \%$ in the case of this study. The size of sample obtained using the formula have shown a total of 402 households. To limit errors and to increase the viability of results, the sample size was adjusted to 602 households which were chosen as sampling and analysis unit, while on-site sanitation facilities were organized and managed as property according the sampling methodology described by Jenkins et al. (2014).

\section{Household survey}

This survey consisted of a 602 semistructured questionnaire administered verbally in French or English to the home owners or the tenants occupying the homes for the longest time in the absence of actual owners. The survey was designed to characterize and describe the sanitation facilities (below and above ground design), to determine the age of the facilities, to document latrine use, to assess operating and maintenance practices. The survey also assessed facility design, emptying preferences and the perceptions of sanitation conditions and problems. At each property, GPS coordinates and respondent socio-economic characteristics (including sex, educational level, number of people living in 
the households and reported monthly income) were collected. This study draws on a sub-set of the survey data related to the facility design, management and functionality, safety and sustainability assessment of on-site sanitation systems in the studied settlements.

\section{Toilet facilities observation}

"Flushing out" is a method of partial emptying of pits which involves inserting a drain or an opening into an exposed or elevated portion of the latrine pit wall, below the slab to release faecal sludge into open environment to be washed away by storm water during rains. In some cases, the rising of water tables during rain events and excess flooding may increase pit sludge levels to the level of the opening, where it is divulged or "vomited" out. In the light of growing concerns over this unsanitary pit-emptying practices, surveyors were trained to look for and record the presence of a "flushing out" pit waste drain pipe during structured on-site observations of each facility. The functional state of the facilities in terms of slab structural conditions, fullness of the waste pit/tank, and aspect of the superstructure were observed. Pit fullness was judged by observing the height of the vacuum space between the slab or cover and the surface of the sludge. To understand barriers for safe emptying, physical accessibility of the property to small car or tanker vehicles was also observed.

\section{Indicators of improved, safe and sustainable sanitation}

The Joint Monitoring Program (JMP) indicators, developed for the Millennium Development Goals with respect to safe and sustainable sanitation (Table 2) were used to access the safety and sustainability of on-site sanitation systems in the study area, according to the methodology adopted by Jenkins et al. (2014). The first three (1-3) indicators assess the technical design of the facility, the next two indicators (4 and 5) assess availability and access to safe faecal waste management services and the last three indicators $(6,7$ and 8 ) assess the functionality of the facility at the time of the survey.

\section{Health risks assessment related to the excreta disposal facilities}

Safe disposal of excreta is critical because agents of a large number of infectious diseases are passed from the body into the excreta (Stenström et al., 2011). These excreted infection agents fall into four main groups: viruses, bacteria, protozoa, and worms (helminths). Excreta, unless properly isolated, can also provide a breeding ground for insects, which may act as either direct or indirect transmitters of disease. Therefore, the health risks related to different on-site sanitation technologies was additionally assessed by investigating the health status of the users. The health risks assessment related to excreta disposal attempts to collect some information about the prevalence and the diversity of excreta-related diseases (cholera, amoebiasis, typhoid fever and helminthiasis) occurred in the past six months in households investigated and the climatic season of occurrence.

\section{Statistical analysis}

All the data from the questionnaires were entered manually using Microsoft Excel 2013. Descriptive statistics tools such as percentages and Chi-square test were used to establish associations between categorical variables. Missing values (associated with the variation of denominators) were not taken into account for data interpretation. The distribution of on-site sanitation in function of the quarters investigated was assessed. Monetary values were adjusted to 2018 values and presented in US Dollars (1 US Dollar = 500 Fcfa). 
Table 1: Different urban settings and the names of settlements investigated in the study area (adapted from Lüthi and Parkinson, 2011).

\begin{tabular}{|c|c|c|}
\hline Different urban settings & Percentage & $\begin{array}{l}\text { Names of settlements investigated in the } \\
\text { study area }\end{array}$ \\
\hline 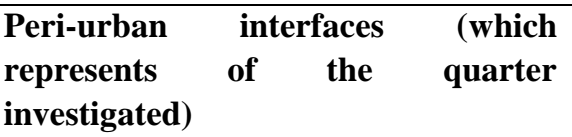 & 18.8 & $\begin{array}{ll}\text { Olembe; } & \text { Ekounou; } \\
\text { Nkolbisson. } & \end{array}$ \\
\hline $\begin{array}{l}\begin{array}{l}\text { Planned and high income } \\
\text { represents which } \\
\text { investigated) }\end{array} \\
\begin{array}{l}\text { of } \\
\text { the }\end{array}\end{array}$ & 18.8 & Bastos; Nkondengui; Mballa II; Nfandena \\
\hline \begin{tabular}{lcc} 
Informal & \multicolumn{2}{c}{ settlements } \\
represents & of & the \\
investigated) & &
\end{tabular} & 40.9 & $\begin{array}{l}\text { Ngoa-Ekele; Etam-Bafia; Ngousso; Emana; } \\
\text { Briquetterie; Carriere; Melen; Nsam; Mvan. }\end{array}$ \\
\hline Middle and high income areas & 22.72 & $\begin{array}{l}\text { Mendong; Biyem-Assi; } \quad \text { Tsinga; } \quad \text { Essos; } \\
\text { Damas. }\end{array}$ \\
\hline
\end{tabular}

Table 2: Indicators for classifying on-site sanitation systems in Yaounde.

\begin{tabular}{|c|c|c|c|}
\hline $\begin{array}{l}\text { System } \\
\text { aspect }\end{array}$ & Indicator description & $\begin{array}{l}\text { Indicator } \\
\text { type }\end{array}$ & $\begin{array}{l}\text { Definition and measurement applied in } \\
\text { this study }\end{array}$ \\
\hline \multirow[t]{3}{*}{$\begin{array}{l}\text { Facility } \\
\text { design }\end{array}$} & $\begin{array}{l}\text { 1- Pit with slab or } \\
\text { better }\end{array}$ & I, SS & $\begin{array}{l}\text { Above-ground technology is basic pit with } \\
\text { slab; build with concrete, brick, rock or other } \\
\text { hard material. }\end{array}$ \\
\hline & $\begin{array}{l}\text { 2- Waste contained in } \\
\text { pit }\end{array}$ & $\mathrm{I}, \mathrm{SS}$ & $\begin{array}{l}\text { Technology has waste pit, septic tank, or } \\
\text { concrete to sewer with no exterior waste } \\
\text { drain pipe observed by enumerator (assumed } \\
\text { if unable to observe) }\end{array}$ \\
\hline & $\begin{array}{l}\text { 3- Below ground } \\
\text { pit/tank lined }\end{array}$ & SS & $\begin{array}{l}\text { Below ground technology is part or fully } \\
\text { lined, septic tank, or is connected to sewer, to } \\
\text { allow for safe waste emptying, and protect } \\
\text { shallow groundwater }\end{array}$ \\
\hline \multirow[t]{2}{*}{$\begin{array}{l}\text { Waste } \\
\text { management } \\
\text { (emptying, } \\
\text { transport, } \\
\text { disposal) }\end{array}$} & 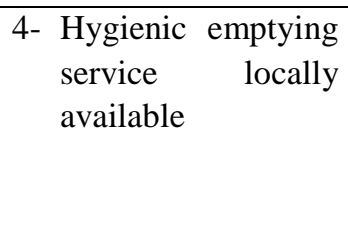 & SS & $\begin{array}{l}\text { Vacuum tanker service to extract pit waste in } \\
\text { sealed tanks and dispose into municipal } \\
\text { treatment systems reported as locally } \\
\text { available, or user intends to use service to } \\
\text { empty in near future }\end{array}$ \\
\hline & $\begin{array}{l}\text { 5- Plot accessible to } \\
\text { hygienic emptying } \\
\text { service vehicles }\end{array}$ & SS & $\begin{array}{l}\text { Enumerator observation of device physical } \\
\text { accessibility (Car, tanker or tug) or actual use } \\
\text { of tanker/tug to empty within last } 03 \text { years }\end{array}$ \\
\hline $\begin{array}{l}\text { Functional } \\
\text { condition }\end{array}$ & $\begin{array}{l}\text { 6- Structurally safe to } \\
\text { use }\end{array}$ & $\mathrm{F}$ & $\begin{array}{l}\text { Enumerator observation that slab/floor is not } \\
\text { collapsing into pit nor in state prohibiting } \\
\text { safe use (assumed if unable to observe and } \\
\text { not reported) }\end{array}$ \\
\hline
\end{tabular}




\begin{tabular}{llll}
\hline $\begin{array}{l}\text { 7- Not completely full } \\
\text { of waste }\end{array}$ & F & $\begin{array}{l}\text { Enumerator observation of pit fullness by } \\
\text { measuring depth from slab/top to surface of } \\
\text { sludge (assumed if unable to observe and not } \\
\text { reported) }\end{array}$ \\
\hline $\begin{array}{l}\text { 8- Facility has half } \\
\text { height walls and } \\
\text { half height door or } \\
\text { more }\end{array}$ & F & $\begin{array}{l}\text { Enumerator observation of toilette facility } \\
\text { superstructure walls, roof, door and height }\end{array}$ \\
\hline $\begin{array}{l}\text { 8A- (high standard) } \\
\text { Facility has roof, full } \\
\text { height walls and door }\end{array}$ & F & $\begin{array}{l}\text { Enumerator observation of toilette facility } \\
\text { superstructure walls, roof, door and height }\end{array}$ \\
\hline JMP definition: hygienically safe and sustainable (SS), and functioning (F) (Jenkins et al., 2014).
\end{tabular}

\section{RESULTS}

\section{Demography of respondent}

The demographic profiles of the investigated populations are presented in the Table 3. The table show the variation (frequency) of the gender of householder, the age group, the educational level, the monthly income as well as the number of person living in household. Generally, the household were dominated by males $(77.7 \%)$ mostly between the ages of 46 to 55 years (26.4\%), majority having a secondary level of education $(45.2 \%)$. With regard to monthly incomes, only $13.5 \%$ of respondents had income above 400 USD. Number of persons per households varied from one (1) to six (6) and above. The education level of some respondents was however low with as much as $24.6 \%$ of respondent attaining only primary school education and $9.5 \%$ without any formal education. This situation may affect the ability of most respondents to understand critical issues regarding the management of on-site sanitation systems. These observations reflect the population and housing census figures of Cameroon, 2015 (Table 3).

\section{Typology of excreta disposal}

The results revealed that there were differences in on-site sanitation system from one urban setting to the other within the study area (Figure 1). Assessment of the variations revealed that traditional pit latrines and septic tanks were the sanitation systems used by most households.
The traditional pit latrines were observed in all the sites but most prevalent in the informal settlements and least in the middle income and high income areas and peri-urban interface. The septic tanks on the other hand were mostly prevalent in planned and high income areas. The "piped equipped latrines" systems, which were observed principally in lowland areas, had the top of the pit connected to a PVC pipe outlet, thus allowing outflow of faecal sludge in the event of flooding. It was noted that $0.5 \%$ of households in informal settlement adopted the "piped equipped latrine" with $2.5 \%$ middle and high income areas also adopting the system. A further $0.5 \%$ of households in planned and high income urban areas had used this system.

One of the main results of this study is that some households did not have any on-site sanitation technologies and thereby practicing open defecation. This practice may occur mostly in households from informal settlement. This practice, which was mostly observed in the informal settlement enclaves constitute a serious environmental risk as it exposes surface and groundwater resources to faecal contamination. About 3\% of households that practiced open defecation were mostly located in the lowland area of the city. It is important to mention that open defecation was not considered as a type of sanitation system but an unapproved option for households which lacked toilet facilities. 


\section{Relation between the on-site sanitation systems and the level of education of households}

To assess the relationship between educational level of respondents and the distribution of the current sanitation systems in households, the 2-sided Pearson Chi-Square correlation test was employed. The results showed a significant correlation between the educational level of householders and the type of on-site sanitation systems in place in the households investigated $\left(X^{2}=79.34\right.$ and $p<0.001)$. The technologies septic tanks, traditional pit latrines and the VIP latrines which can be assimilated to improve sanitation systems were widely spread in households where the head attended higher education, secondary school and primary school (Figure 2). The distribution of septic tank systems which is the most improved sanitation technologies found in the study area were $11.71 \%, 1.52 \%, 8.65 \%$ and $19.35 \%$ respectively for households where the respondents attended higher education, never went to school, attended primary school and secondary school. The traditional latrines were mostly represented in households were the head attended secondary school (25.29\%), primary school $(13.75 \%)$ never went to school $(6.28 \%)$ and higher education (6.62\%). According to the VIP latrines, the frequencies of the distribution of these on-site sanitation technologies in the households are $0.50 \%$, $0.17 \%$ and $0.34 \%$ respectively for households which the head attended higher education, primary school and primary school.

Looking at the piped equipped latrines, the households with these types of sanitation technologies were mostly attended the primary school $(1.35 \%)$, the secondary school $(0.50 \%)$ and who never attended school $(1.52 \%)$. The open defecation practices were found at all educational level and it is mostly represented in households who attended primary school $(1.18 \%)$ and secondary school $(0.67 \%)$.

\section{Relation between the on-site sanitation systems and the monthly income of households}

To assess the effect of monthly income of households on the distribution of the current defecation practices at the household level, the 2-side Pearson Chi-Square correlation test was employed. The results showed significant effects on the distribution of sanitation systems in the households investigated $\left(X^{2}=83.501, p<0.001, \mathrm{n}=364\right)$. In general, the unimproved sanitation practices (i.e. the prevalence of open defecation practice and the distribution of pipe latrines in households) were found to be widespread in households with low income (under 100 USD, 100 to 200 USD, 200 to 300 USD) while the septic tank systems which represent an improved sanitation technologies were mostly represented in households with higher incomes (300 to 400 USD and over 400 USD) (Figure 3).

\section{Latrine characteristics \\ Number of persons using the facilities}

An important variation in the number of persons using the latrines was recorded. This number of persons varied depending of the investigated quarters and ranged between one to more than six people (Figure 4). However, latrines visited by more than 6 persons were mostly represented in the study area $(32.39 \%, n=559)$ while the latrines used by one person were less represented $(14.45 \%$, $\mathrm{n}=559$ ). The number of persons using the latrines in the households was found to display with the number of people living in the households. This observation could be explained by the fact that people in the study area did not share their latrines with other external users as it is contrary observed in other countries where the number of user of latrines may be sometimes more than the number of people living in the household.

\section{Building materials}

Based on the field observations, several building materials were used by households to build their latrines (Figure 5). 
Most of the latrines were built with concrete (83.98\%, $\mathrm{n}=586)$ while other where built with materials like metal sheets $(4.72 \%, \mathrm{n}=586)$, beaten earth $(2.27 \%, \mathrm{n}=586)$, wood $(6.75 \%$, $\mathrm{n}=586)$ and plastic materials $(2.28 \%, \mathrm{n}=586)$. Assessment of the distribution of latrine building materials in function of the level of education and monthly income of households using the 2-sided Pearson Chi Square test revealed $56.7 \%$ and $63.9 \%$ of variations respectively. The latrine building materials used by the surveyed populations strongly depended on the educational level of householders $\left(X^{2}=64.80 ; p=0.004\right)$ as well as their financial incomes $\left(X^{2}=41.07 ; p<0.001\right)$ (Figure 6 and Figure 7). It can be concluded that the sanitation technologies used in the surveyed populations strongly depended on the educational level and the monthly income of the population.

\section{Desludging periods}

When the pits of latrines are full, several actions are carried out by the latrine users (Figure 8). Most of respondents mentioned the emptying of their pits $(74.10 \%$, $\mathrm{n}=583$ ), $21.10 \%$ mentioned the addition of chemical substances (caustic soda, wood ache) and only $4.80 \%$ mentioned the construction of another latrine. The later cited options where recorded in households which did not face space problems. Within the facilities emptied, $50.99 \% \quad(n=557)$ of respondents mentioned that they usually empty the pit of their latrines within a period not less than two times/year, $12.39 \%(\mathrm{n}=557)$ empty their latrines two time/year, $18.31 \%$ $(\mathrm{n}=557)$ with a period of three times/year, $10.77 \%(\mathrm{n}=557)$ of respondents empty their latrine four times/year, and $7.54 \% \quad(n=557)$ within a period of more than four times/year.

To assess the relationship between the types of on-site sanitation systems and the variation of desludging periods within the surveyed population, the cross correlation using the 2-sided Pearson Chi-Square tests was employed. The test revealed $53.3 \%$ of the variability of emptying periods within the surveyed population with a strong significant effects of the types of sanitation systems $\left(X^{2}=\right.$ $371.30 ; p<0.001$ ) (Figure 9). Looking at the septic tank facilities, the desludging frequencies recorded in the study area were $49.79 \%, 14.97 \%, 23.07 \%, 6.48 \%$ and $5.67 \%$ respectively for the desludging frequencies less than two times per year, three times per year, four times per year and more than four times per year $(n=247)$ (Figure 10). For the traditional pit latrines, the frequencies of the desludging periods recorded were in order of $56.09 \%, 4.18 \%, 14.98 \%, 13.58 \%$ and $4.18 \%$ respectively for the desludging frequencies less than two times per year, three times per year, four times per year and more than four times per year $(n=287)$. According to the 'piped equipped latrine', the desludging period frequencies recorded were $84.21 \%$ and $15.79 \%$ respectively four times per year and more than four times per year $(n=19)$. The variation recorded in the distribution of the desludging frequency may be due to the variation of the number of latrine users, the volume of the pits, the available space in the household as well as the socioeconomic status of households.

\section{Comfort of use}

On the basis of the survey information and field observations collected, the significant variation of respondent's opinion looking at the problems related to the comfort of toilet facilities was observed $\left(X^{2}=204.408\right.$, $p<0.001, \mathrm{n}=368)$. The spread of bad odours was observed in most of the toilets investigated with a higher prevalence recorded in the 'piped equipped latrines' $(>80 \%, n=20)$ (Figure 11). The case of insecurity was observed in households practicing open defecation $(71.42 \%, \mathrm{n}=14)$ and those who used the traditional pit latrines $(11.25 \%$, $\mathrm{n}=244)$. Exposure was observed in some of the septic tanks $(15.78 \%, \quad n=90)$ and traditional pit latrines $(17.21 \%, \mathrm{n}=244)$. Some pictures of unsafe facilities with discomfort are presented in Figure 12.

Indicators of improved, safe and sustainable sanitation systems

To classify the on-site sanitation systems investigated as improved, hygienically safe, sustainable and functioning, the WHO/UNICEF JMP indicators was 
applied. Looking at the facility design, $85.36 \% \quad(\mathrm{n}=568)$ of latrines with slab (indicator 1) build with concrete, brick, rock or other hard material (Figure 13). In 68.79\% $(\mathrm{n}=568)$ of the facilities investigated, wastes were contained into the pit/tanks of latrines without overflow to the surrounding areas (indicator 2) and 62.85\% ( $\mathrm{n}=568)$ of latrines had below ground pit/tank lined allowing the safe waste emptying and the protection of shallow groundwater (indicator 3). Looking the waste management practice, $58.97 \%$ $(n=568)$ of households were accessible by the vacuum tanker services for the extraction of faecal sludge in the pit of latrines (indicator 4), $52.62 \%(n=568)$ of pits were accessible to hygienic emptying service vehicles (tanker or tug) (indicator 5).

The functional conditions of the toilet facilities were also investigated and $90.23 \%$ $(\mathrm{n}=568)$ of the latrines investigated was not completely full (indicator 7), 66.85\% ( $\mathrm{n}=568)$ had half wall/door (indicator 8) and only $28.75 \%(n=568)$ of the facility has a cabin containing full height walls, a full height door and a roof (indicator 8a). The variation of the WHO/UNICEF JMP indicators observed in the study area may be explained by the differences observed in the monthly incomes, level of education of householders as well as the willingness of householders to pay for access to an improve and sustainable sanitation system.

\section{Sanitary and environmental risks associated with the current defecation practices in surveyed households}

Based on the survey results, $61.30 \%$ $(n=598)$ of the investigated population have suffered from several cases of faecal-oral transmitted diseases (amoebiasis, cholera, helminthiasis, thyphoid fever) within the past six months (Figure 14) with the difference of prevalence between current defection practices in households (Figure 15). It appears that the faecal-oral transmitted diseases were less prevalent in households with septic tanks as toilet facility (only $31.07 \%$ of diseases prevalence recorded) in comparison to the households with traditional pit latrines as toilet facility $58.84 \% \quad(\mathrm{n}=311)$ of diseases prevalence recorded. The VIP latrines users did not mention the prevalence of faecal-oral transmitted diseases contrary to the households practicing open defection. The significant correlation between the prevalence of faecal-oral transmitted diseases and the type of on-site sanitation was found $\left(X^{2}=\right.$ 163.03, $p<0.001, \mathrm{n}=598)$ as well as the distribution of the type of faecal-oral transmitted diseases recorded in the households $\left(60 \%\right.$ of variation, $X^{2}=170.29$, $p<0.002, \mathrm{n}=293$ ) (Figure 16). A maximum rate of prevalence was recorded in households using traditional latrines as toilet facility and no disease was recorded in households using VIP latrines as toilet facility. According to the variation of the type of faecal-oral transmitted diseases recorded in relation to the toilet facilities used in households, typhoid fever were the most prevalent diseases. The prevalence distributions recorded were in the order of $38.58 \%, 26.69 \%$ and $55 \%$ respectively for traditional pit latrine, septic tank and piped equipped latrine. The prevalence recorded for amoebiasis which is the second case of disease recorded in the study area after the typhoid fever were in the order of $11.57 \%, 1.59 \%, 30 \%$ and $35.71 \%$ respectively for traditional pit latrine, septic tank, piped equipped latrine and open defecation. We mentioned that open defecation in this study is considered as current defecation practices found in households who did not have on-site sanitation technology. The prevalence of helminthiasis in the studied households were in the order of $6.10 \%, 2.39 \%, 10 \%$ and $10 \%$ respectively for the traditional pit latrine, septic tank, piped equipped latrine and open defecation. For the cholera disease, the prevalence recorded were in the order of $2.25 \%, 0.32 \%$ and $0.32 \%$ respectively for the traditional pit latrine, septic tank and open defecation. The prevalence of the faecal-oral transmitted diseases in the study area may be due to the weak maintenance as well as the sanitation and hygiene conditions during the management of the toilet facilities in households. 
Table 3: Sociodemographic characteristics of study respondents.

\begin{tabular}{|c|c|c|c|}
\hline Parameters & Variable & Percent & National Values* \\
\hline \multirow{3}{*}{ Gender } & Female & 22.30 & $49.75 \%$ \\
\hline & Male & 77.70 & $50.25 \%$ \\
\hline & Total & 100.0 & 100 \\
\hline \multirow{5}{*}{ Age group (years) } & 18 to 25 & 23.30 & \multirow{5}{*}{$\begin{array}{l}\text { Under } 15 \text { to more than } \\
60 .\end{array}$} \\
\hline & 26 to 35 & 11.10 & \\
\hline & 36 to 45 & 20.30 & \\
\hline & 46 to 55 & 26.40 & \\
\hline & Over 56 & 18.90 & \\
\hline \multirow{6}{*}{ Educational level } & No response & 2.20 & 1 \\
\hline & Never went to school & 9.50 & $14.30 \%$ \\
\hline & Primary school & 24.60 & $35.50 \%$ \\
\hline & Secondary school & 45.20 & $30.80 \%$ \\
\hline & Higher education & 18.60 & $17.40 \%$ \\
\hline & Total & 100.0 & 100 \\
\hline \multirow{7}{*}{ Monthly income } & No response & 39.40 & \multirow{7}{*}{$\begin{array}{l}\text { Under } 80 \text { USD to more } \\
\text { than } 450 \text { USD }\end{array}$} \\
\hline & Under 100 USD & 13.30 & \\
\hline & 100 to 200 USD & 11.80 & \\
\hline & 200 to 300 USD & 15.90 & \\
\hline & 300 to 400 USD & 6.10 & \\
\hline & Over 400 USD & 13.50 & \\
\hline & Total & 100.0 & \\
\hline \multirow{6}{*}{$\begin{array}{l}\text { Number of person } \\
\text { living in households }\end{array}$} & No response & 7.10 & \multirow{6}{*}{$\begin{array}{lr}\text { One person to more } \\
\text { than } 6 \text { persons } & \text { (with } \\
\text { about } 40 \% & \text { of } \\
\text { households of } & \text { more } \\
\text { than } 6 \text { persons). } & \end{array}$} \\
\hline & One person & 14.50 & \\
\hline & 2 to 4 persons & 23.30 & \\
\hline & 4 to 6 persons & 22.80 & \\
\hline & More than 6 persons & 32.20 & \\
\hline & Total & 100.0 & \\
\hline
\end{tabular}

"National values based on Population and Housing Census of Cameroon (2015).

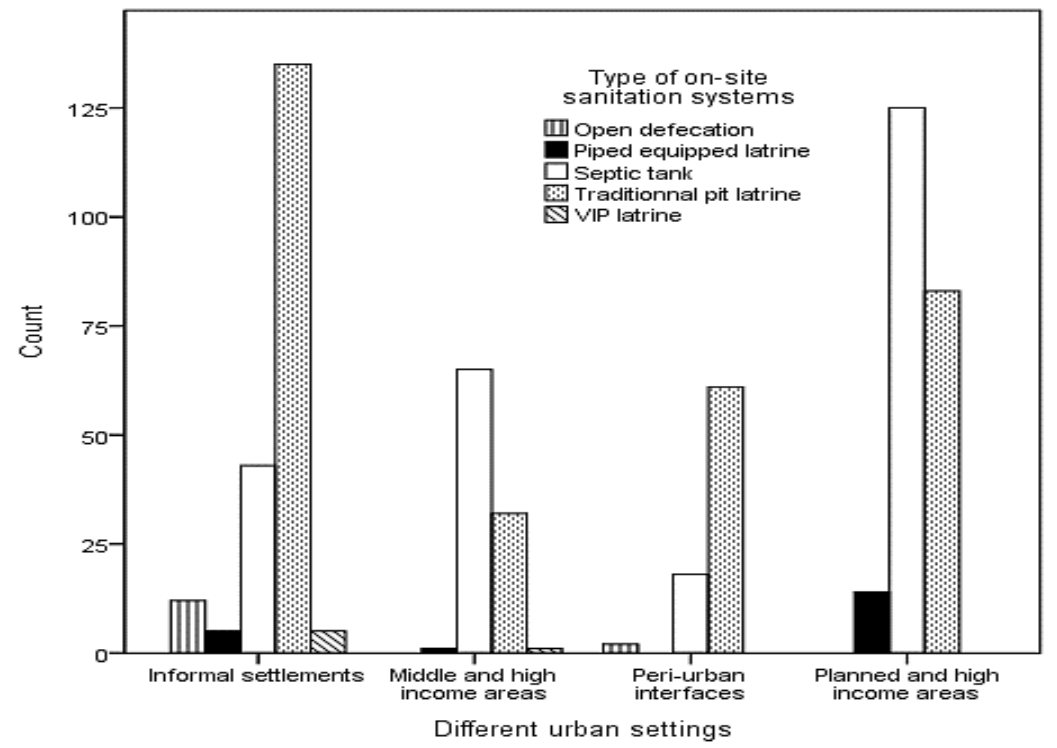

Figure 1: Distribution of the different toilet facilities in relation to the different urban settings. 


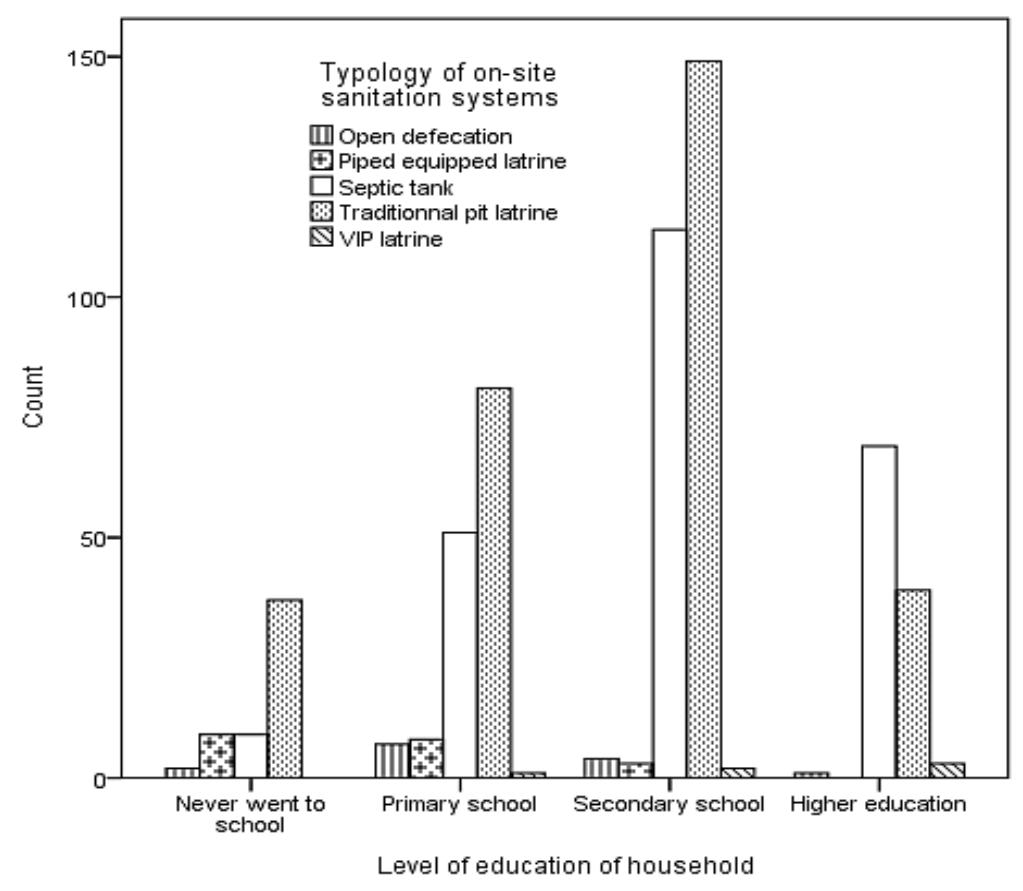

Figure 2: On-site sanitation variation systems in used in the investigated households in relation to the level of education.

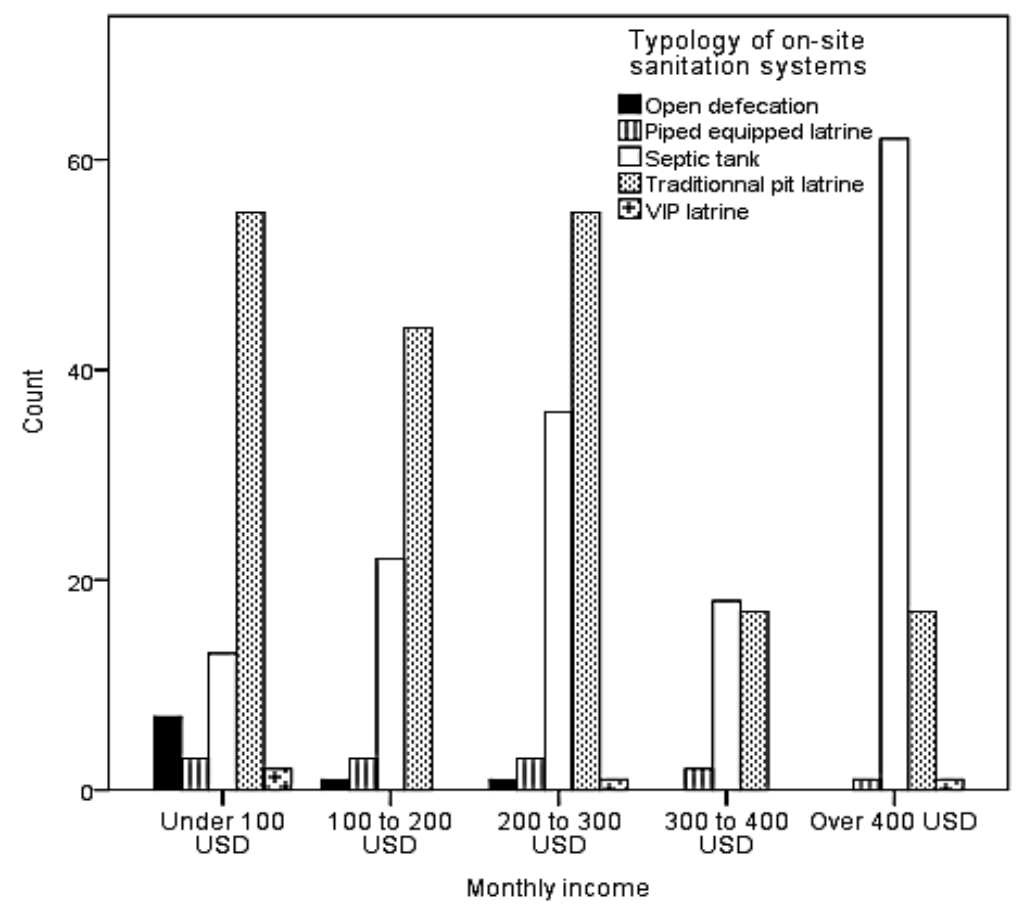

Figure 3: On-site sanitation variation systems at the household levels in relation to the monthly income of households. 


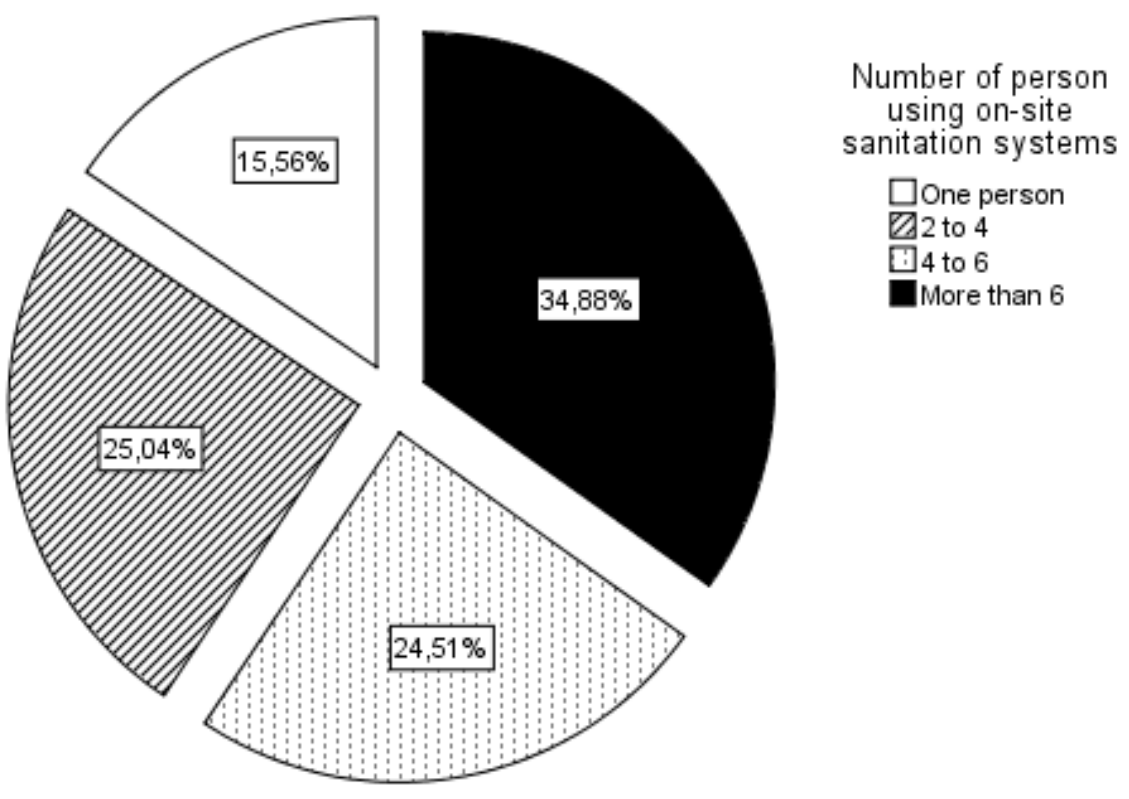

Figure 4: Representation of the number of person using the latrines (percentage) in the investigated households.

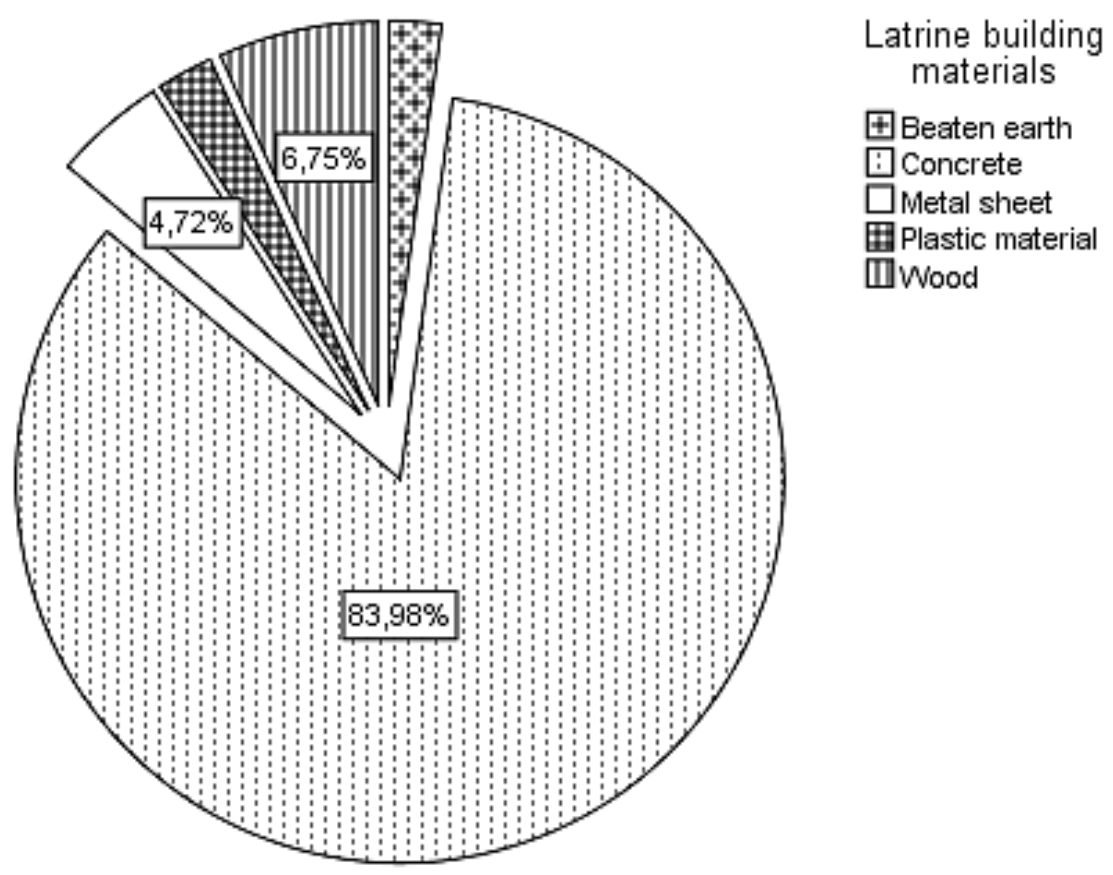

Figure 5: Variation of the materials used to build latrines in the studied population. 


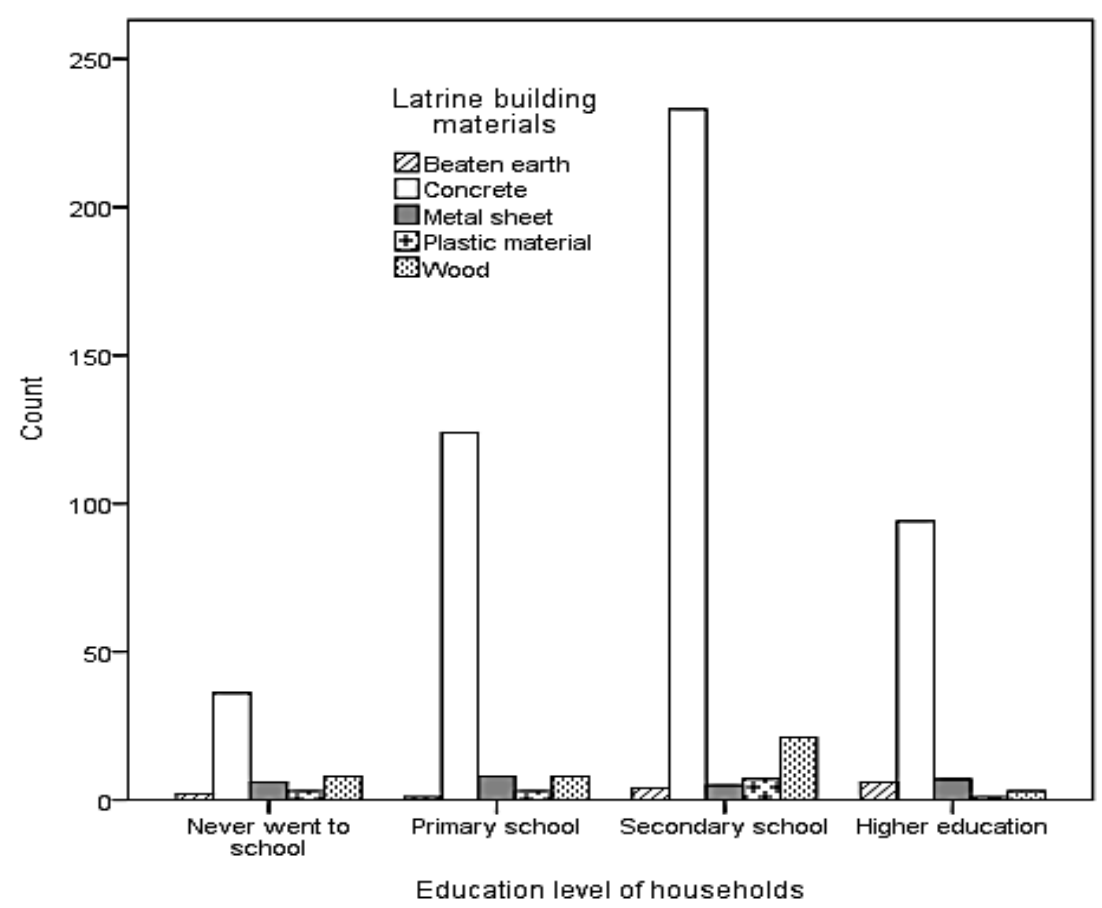

Figure 6: Variation of the latrine building materials in relation to the level of education of households.

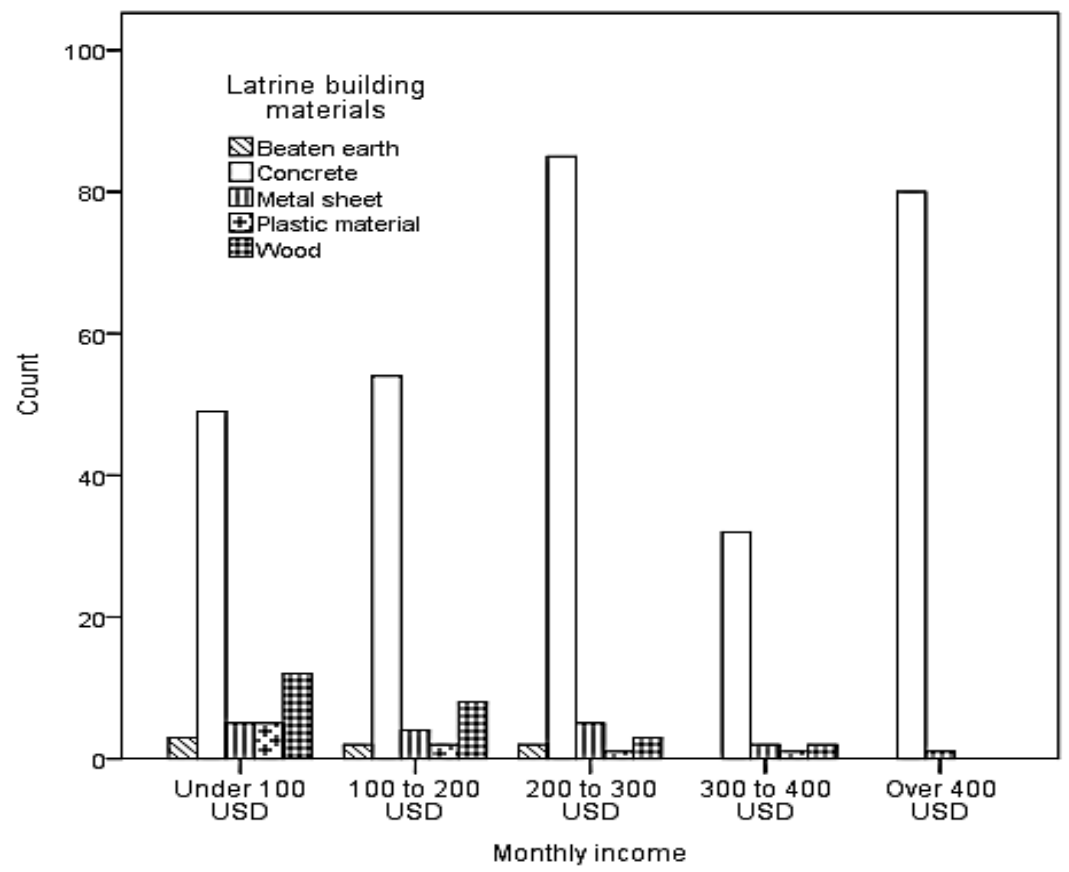

Figure 7: Variation of the latrine building materials in relation to the monthly income of households. 


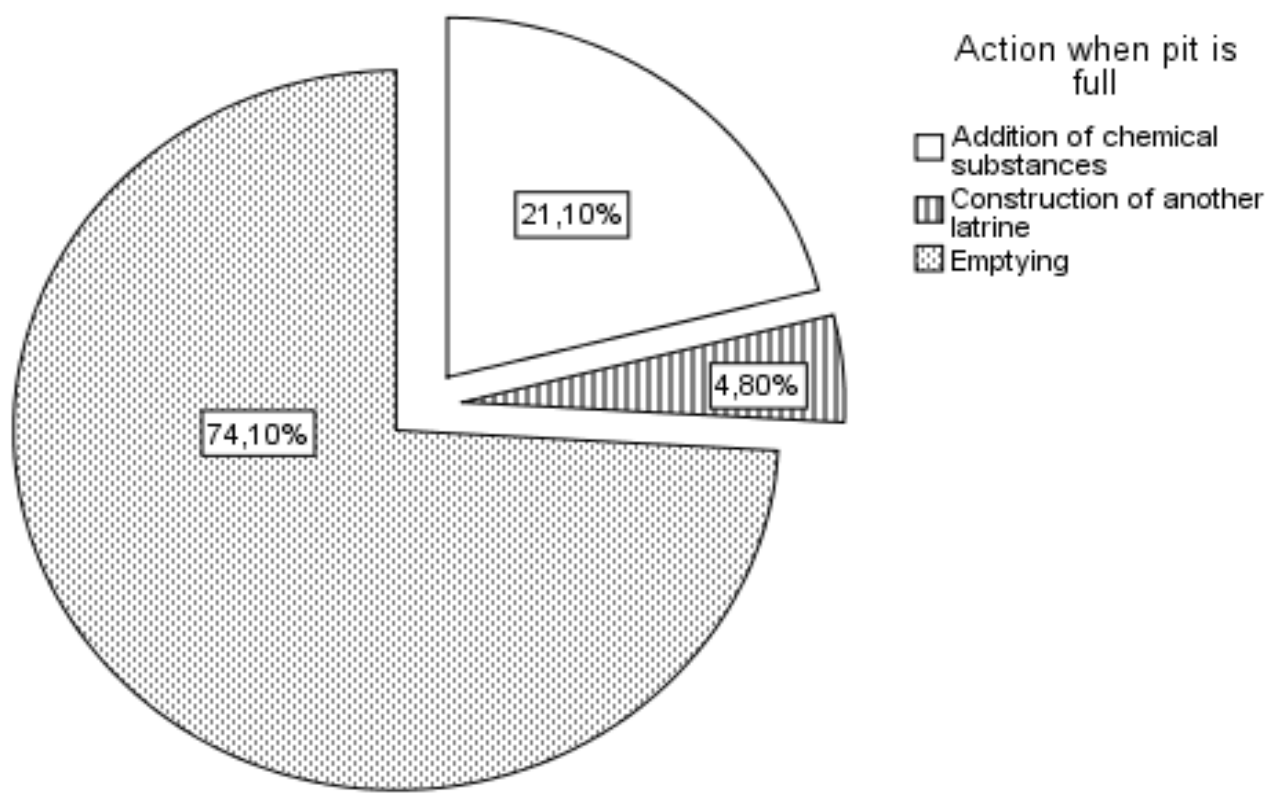

Figure 8: Distribution of respondent's opinions per actions needed to be done when the pits of latrines is full.

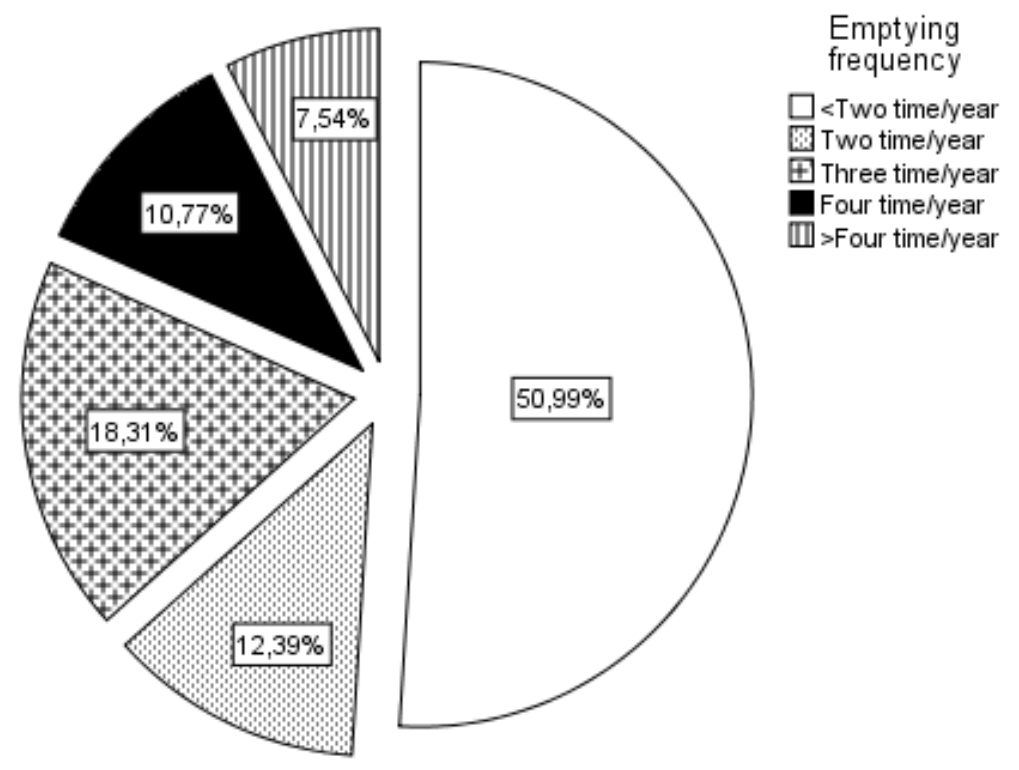

Figure 9: Variation of the frequency of desludging in surveyed households. 


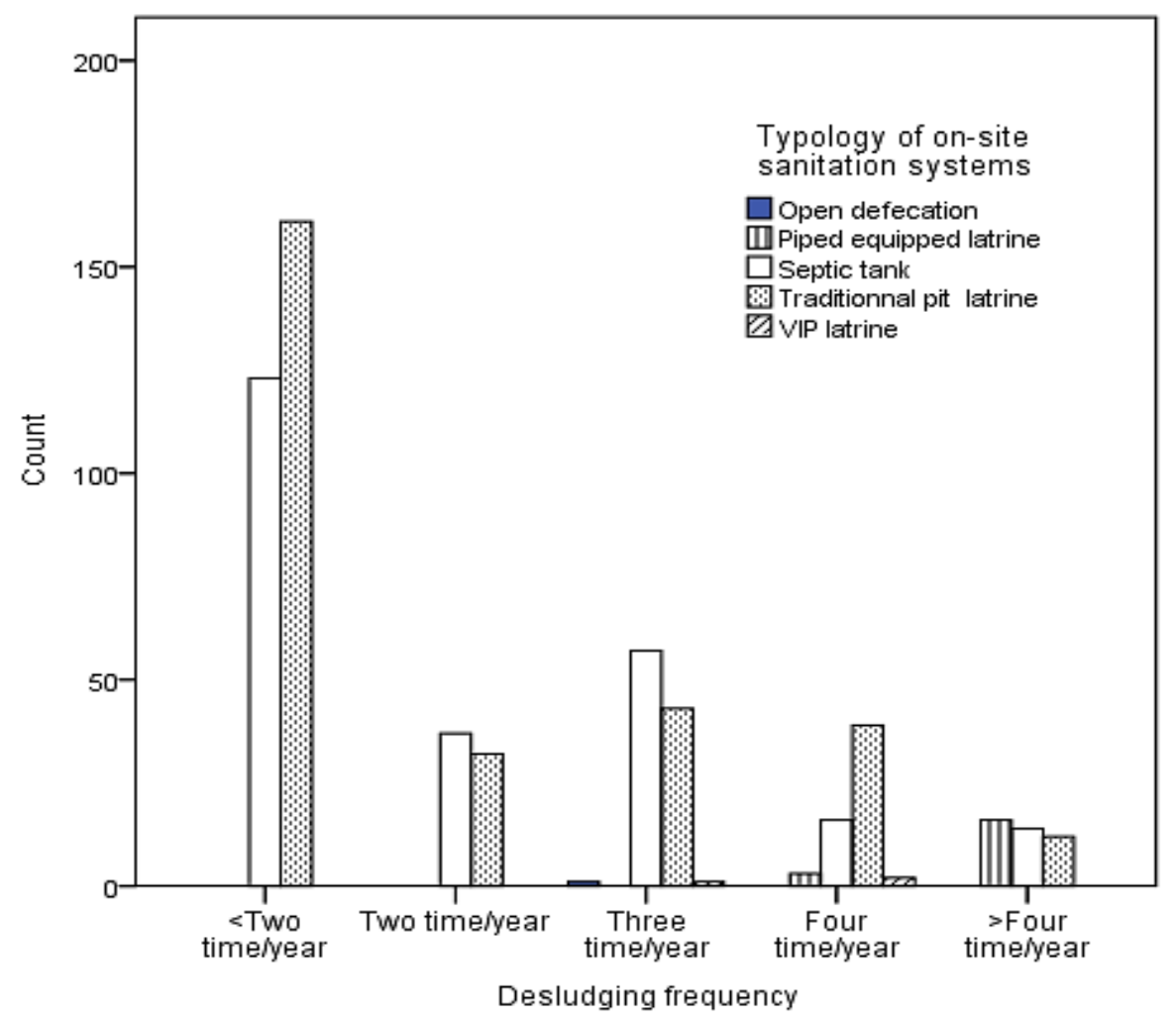

Figure 10: On-site sanitation variation systems typologies in relation to the desludging frequencies.

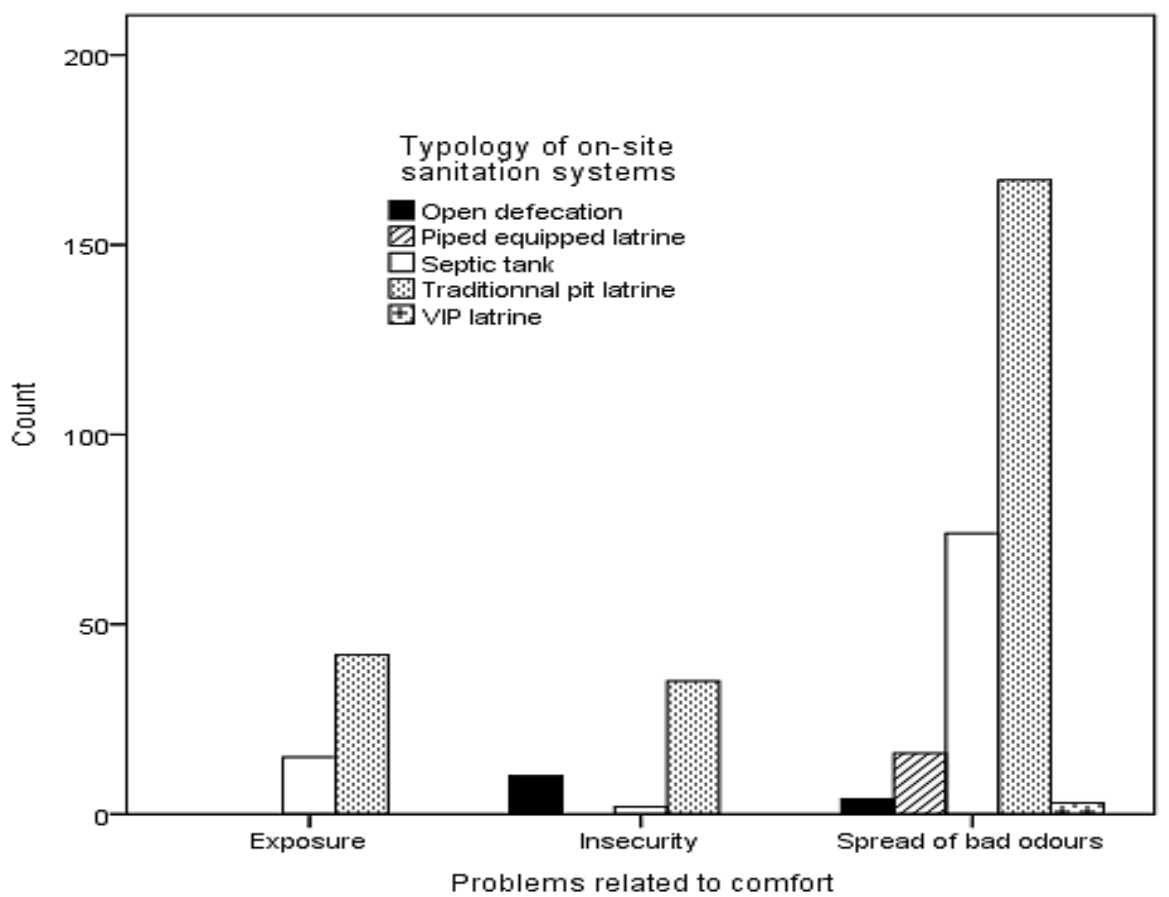

Figure 11: Distribution of problems facing households in relation to the type of on-site sanitation systems. 


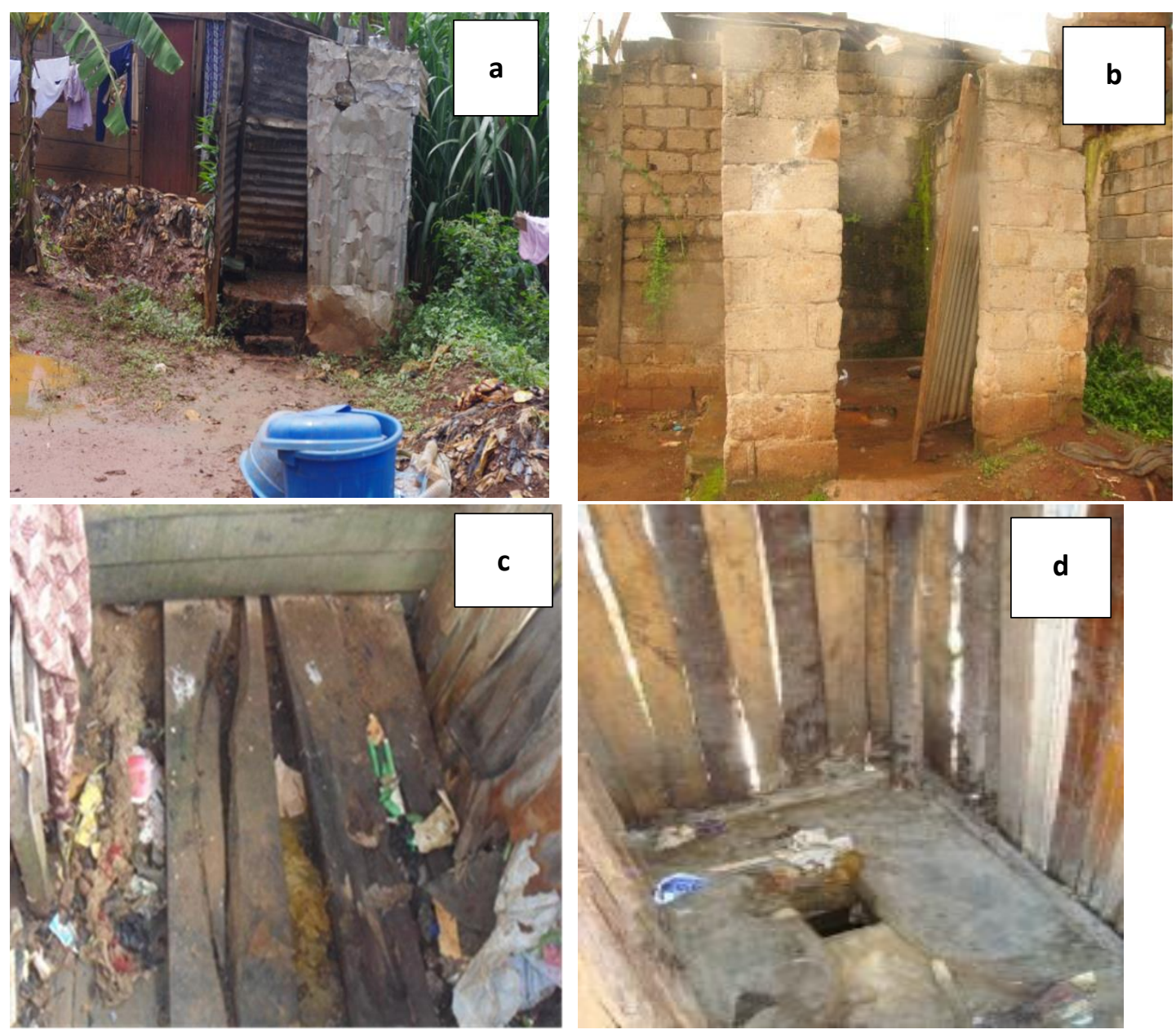

Figure 12: Photos showing some unsafe latrines with discomfort found in the study area (a: dirty latrine built with metal sheet located in a flooding area; $b$ : latrine with unfinished superstructure showing weak maintenance; c: unsafe latrine with a wood slab partially built and full pit continuously in used; d: dirty latrine with partially built superstructure) (Photos: Letah Nzouebet).

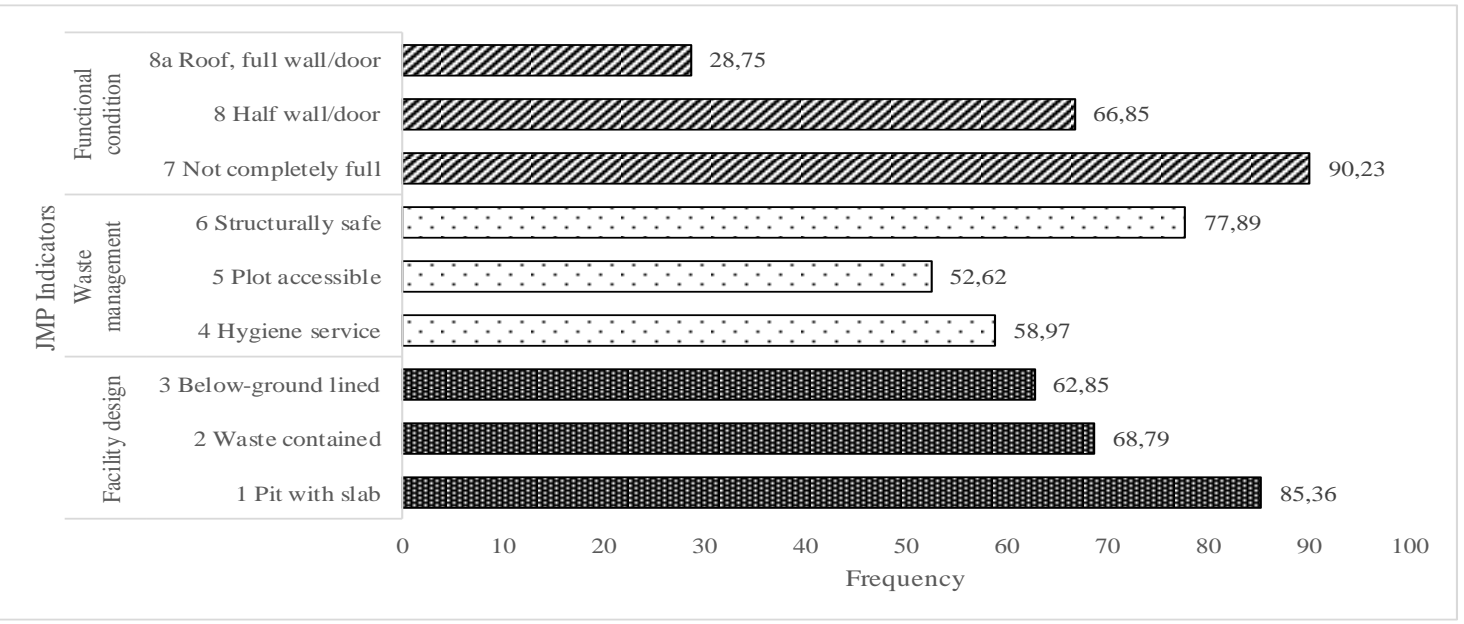

Figure 13: Indicators prevalence of improved, safe and sustainable sanitation systems. 


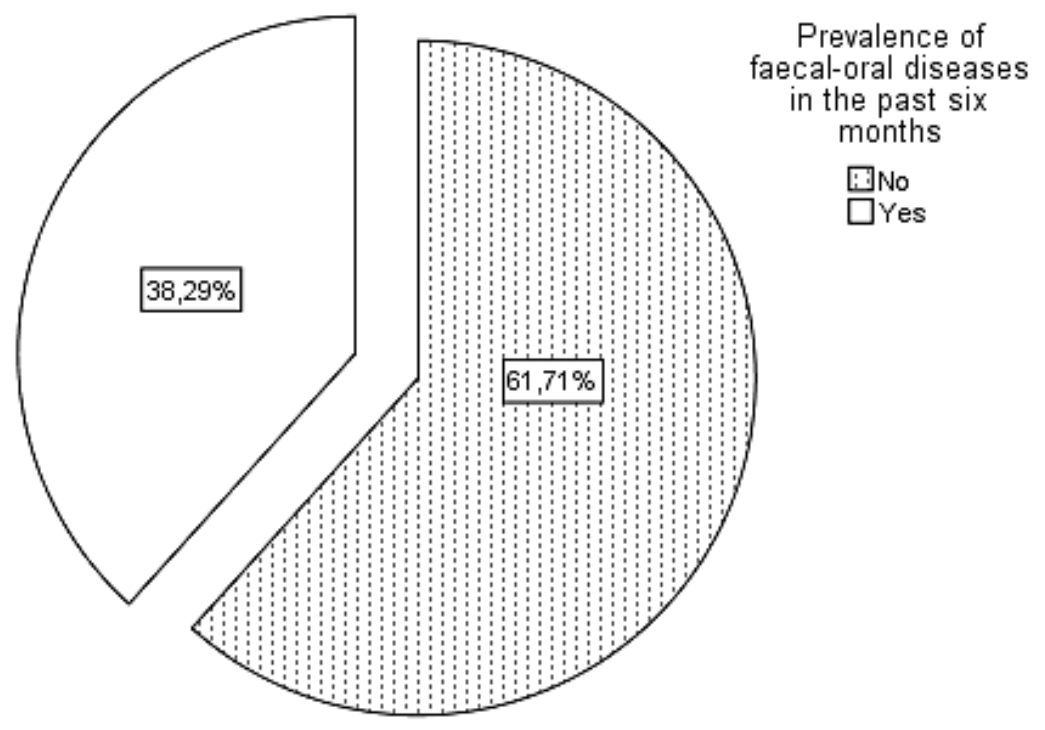

Figure 14: Prevalence of faecal-oral diseases in the surveyed population.

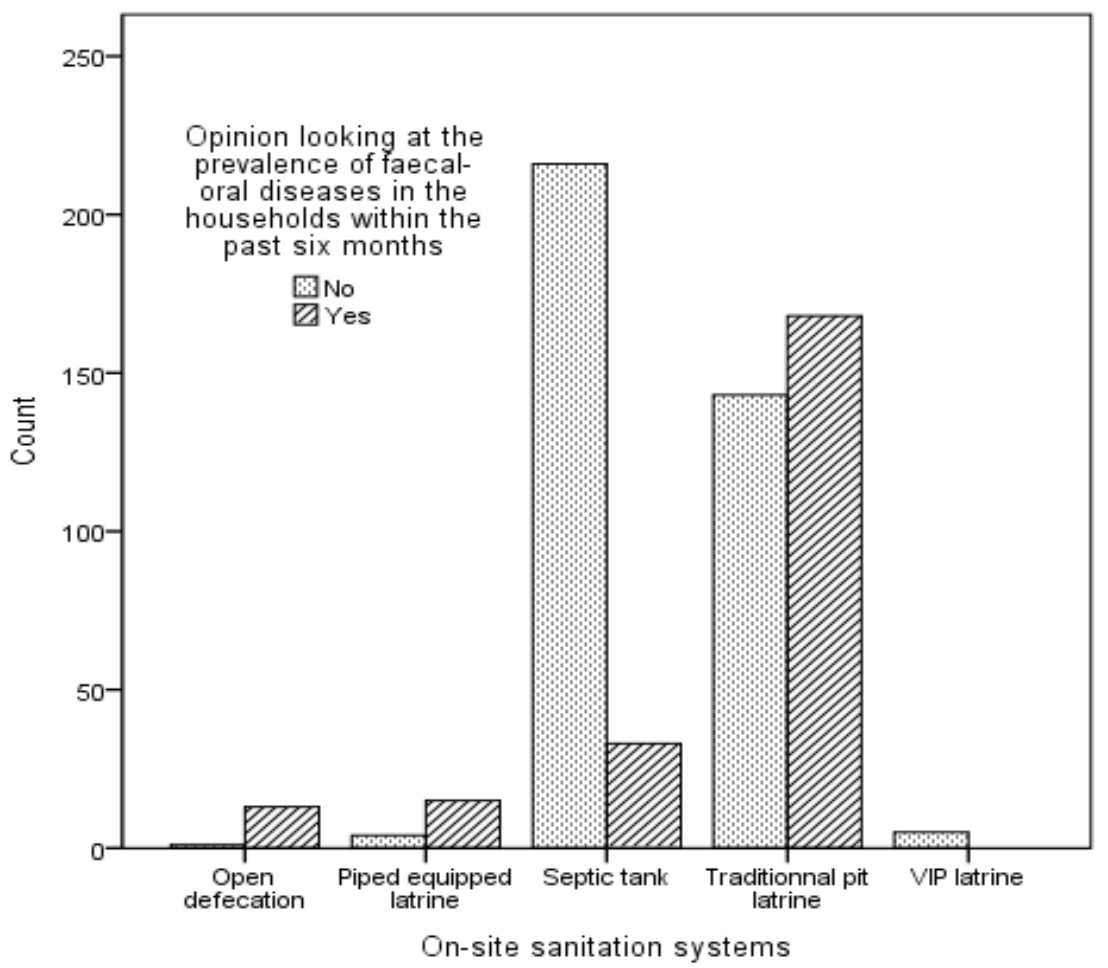

Figure 15: Prevalence variation of faecal-oral diseases in relation to the toilet facilities in used in households. 


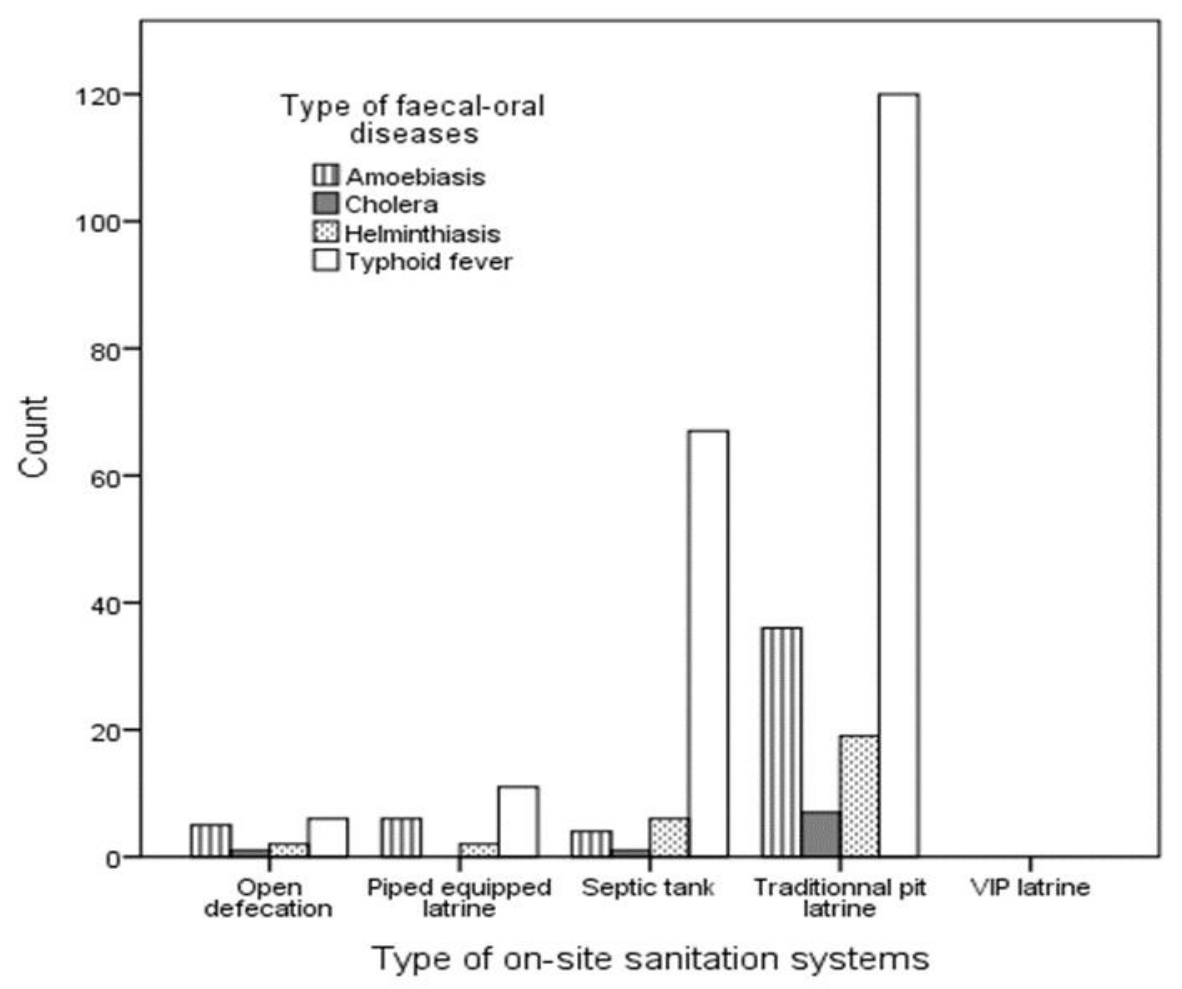

Figure 16: Variation of the type of faecal-oral diseases recorded in relation to the toilet facilities in used in households.

\section{DISCUSSION}

\section{Typology of on-site sanitation}

The finding of this study revealed that there were differences in on-site sanitation system from one urban setting to the other within the study area. Similar observation was made by Letah Nzouebet et al. (2016) working on the prevalence and diversity of intestinal helminth eggs in pit latrine sludge of a tropical urban area. The authors pointed out that several sanitation technologies in the study area were constituted of septic tanks, traditional pit latrines, ventilated improved pit latrines and piped equipped latrines. Indeed, the results of Cheng et al. (2018) working on the toilet revolution in China revealed several methods of improved sanitation technologies which are represented by septic tanks, doublevault funnel latrine, double pit alternate type, biogas-linked toilet, urine-faeces diversion latrine and integrated flushing latrine. In addition, the finding Stenström et al. (2011) who assessed microbial exposure and health assessments in sanitation technologies and systems in tropical area found that open defecation is widespread in developing countries and is the most significant environmental factor involved in the transmission of sanitation-related diseases.

Relationship between the on-site sanitation systems and the level of education of households

This study showed a significant correlation between the educational level of householders and the type of on-site sanitation systems in place in the households investigated. Similar findings was obtained by Jenkins et al. (2014) who revealed the strong effects of educational level of households and the type of on-site sanitation systems when assessing excreta disposal in Tanzania. According to these authors, well-educated households often know more information on adequate emptying frequency, choosing qualified mechanical emptying services and ensuring environmental and health safety for the surrounding population. Additionally, 
Brown et al. (2015) pointed the difficulty to achieve a change in excreta disposal practices as they are part of the basic behavioural pattern of a community. As unsafe practices, the open defection found in the study area constitutes a significant health risk to populations through contamination of ground and surface water resources. Indeed, Bartram and Cairncross (2010) stated that about 2.4 million deaths (4.2\% of all deaths) could be prevented annually if everyone practised appropriate hygiene and had good and reliable sanitation technologies at household levels.

\section{Relationship between the on-site sanitation systems and monthly income of households}

This study showed significant effects of the monthly income on the distribution of on-site sanitation technologies in the households investigated. It revealed that the good sanitation practices in the study area may strongly depend on the household's income. This is the main reason why the number of latrines observed in the low income households were half constructed and do not have permanent roofs and doors in some cases. The strong correlation between the household incomes and the type of sanitation systems used in households was addressed in the literature (Bakare et al., 2015). The authors demonstrated the strong implication of the inadequate financial resources on the weak coverage of improve sanitation technologies in Tanzania and Senegal respectively.

\section{Latrine characteristics}

The variation of the number of persons using the on-site sanitation systems was recorded in this study and this number is proportional to the number of persons living in the households. This current situation found in the study area could be explained by the practice of non-sharing latrines. Indeed, Jenkins et al. (2014) by assessing the sanitation access in rapidly expanding informal settlement in Tanzania revealed that the practices of sharing latrine is common at mixed landlord-tenant and tenant only residences compared with family occupied residences were this practices is very low or absent. These authors pointed out the economic factors, like the sharing of latrine involved several contributions from multiple users in building, maintenance and operating a shared facility. According to the latrine building materials, several building materials were used by households to build their latrines with most of the latrines built in concrete. Similar observations were done by Bakare et al. (2012) assessing the excreta disposal in Dar-es-Salaam (Tanzania). The authors mentioned the variation of the latrine building materials to be strongly affected by educational level coupled to the financial resources. For these authors, low education is the main reasons for low-paying jobs performed by householders with an implication on the investment into good excreta disposal facilities. Looking at the desludging periods, several variation were recorded and could be due to the variation of the number of latrine users, the volume of the pits, the available space in household as well as the socioeconomic status of households. Indeed, the findings of Nakagiri et al. (2016) working on the characterisation of pit latrines sludge in urban areas of Sub-Saharan Africa mentioned the high variation in the pit latrine depths and the number of latrine users as main factor which may affect the pit filling rate. Additionally, Bakare et al. (2012) demonstrated the high-water table to be the main causes of the pit's filling rate. The pipe equipped latrines identified during this study and which is usually located near the water table showed a higher desludging period of more than four times per year. According to the literature, the number of latrine users could strongly affect the rate of faecal sludge accumulation in the pits of latrines as the excreta production rate per person was estimated at about 0.12 to 0.40 litre of faeces and 0.6 to 1.5 litre of urine per day (Bakare et al., 2012). In addition, the work of Cheng et al. (2018) pointed out about a million tons of faecal sludge collected yearly in public toilet in urban area of China. Furthermore the study done by Gning et al. (2017) in Dakar pointed out the absence of regulations by the Senegal Government in term of the cost of desludging paid by households for having access to the mechanical emptying service. This could also 
be one of main reasons of the setbacks in the context of the study area since most of the investigated households did not have access to a clean safe hygienic mechanical emptying service.

Some unsafe latrine facilities with discomfort were found in the study area. This discomfort is the spread of bad odours, insecurity and exposure. The finding of this study corroborate with those of Bakare et al. (2012). The authors pointed out the prevalence of unsafe latrine technologies in South Africa. Additionally, the inquisitive eyes that may occur during open defecation, as reported in this study is found to be particularly disadvantageous to women who are prone to sexual abuse while finding places to ease themselves. The variation of the WHO/UNICEF JMP indicators was observed in this study. This variation may be due to the differences observed in the monthly incomes, level of education of householders as well as the willingness of householders to pay for access to an improve and sustainable sanitation system. Indeed, Taweesan et al. (2015) by assessing accelerating uptake of inhouse toilets of a rural community in Ghana pointed out the financial limitation to constructing improved in-house latrines. In addition, the literature pointed out the variation of the JMP indicators to be affected by the level of education (Jenkins et al., 2014; Brown et al., 2015).

\section{Sanitary and environmental risks associated with the current defecation practices in the surveyed urban areas}

The current defecation practices in households were found to be associated to sanitary and environmental risks. Indeed, the empirical evidence provided by Tumwebaze et al. (2013) suggests that toilets facilities end up in a deteriorated state and pose health risks since users fail to adequately maintain them. Additionally, Taweesan et al. (2015) revealed adequate sanitation as one of the fundamental key factors for good health and socioeconomic development. Also, the improvement of sanitation technologies can substantially reduce the rate of morbidity and severity of various diseases affecting the quality of life particularly for children (Mara et al., 2010; Stenström et al., 2011; Cairncross et al., 2010). Furthermore, lack of hand washing may be the cause of the prevalence of faecal-oral transmitted diseases found in the study area. According to the findings of Wolf et al. (2018) working on the impact of drinking water, sanitation and hand washing with soap on childhood diarrhoeal disease, the authors reported the association between improved household sanitation facilities and diarrhoea compared with unimproved sanitation and two observations respectively of sewer connection compared with unimproved and improved sanitation facilities. For Mathew et al. (2017) working on the systematic review and meta-analysis of the impact of sanitation on infectious diseases and nutritional status showed the positive impacts of sanitation on the aspects of health. However, the role of the health sector in improving sanitation is fundamental for the promotion of sanitation in environmental health planning at the local and national level. Thus, behaviours should be changed to increase householders' demand for sustained use of excreta disposal facility. According to Tumwebaze et al. (2013), the enforcement role of the health sector is particularly important in urban areas where high- living density increases the risks of faecal contamination in the environment and where one person's lack of sanitation can affect the health of many other people. In the fact, Koné et al. (2016) pointed out the necessity of the safe treatment of faecal sludge coming mainly from on-sanitation technologies in order to minimize the risk of infections along the faecal sludge management chain.

\section{Conclusion}

The objective of this study was to present a detailed assessment of excreta disposal facilities in 602 randomly selected households in the city of Yaounde (Cameroon). The study aimed at proposing and applying a set of indicators to characterize and assess the hygienic safety and sustained functioning of the existing device, including locally available excreta disposal, according to JMP definitions and the assessment of the 
health status of latrine users. The results showed that several mods and characteristics of individual sanitation are closely related to the standard of households as well as the household incomes and the level of education. Also, the observed heterogeneity of sanitation systems is related to the standard of the surveyed households, the monthly income and the level of education. The latrine facilities were different in terms of number of users, emptying modes and frequency, as well as building material. The respondents using inadequate toilet facilities are suffering from faecal-oral transmitted diseases, with higher prevalence in rainy seasons. The finding of this study may have important implications for defining what constitutes 'improved' sanitation for poor populations living in unplanned informal settlements.

\section{COMPETING INTERESTS}

The authors declare that they have no competing interests.

\section{AUTHORS' CONTRIBUTIONS}

WALN contributed to the design of the study, wrote the protocol, elaborated the survey methodology used on the field, analysis of data and wrote the first draft of the manuscript. ESK conducted analysis of data and scientific orientation of the manuscript. GVDW and CW contributed to the elaboration of the survey methodology used on the field. AR reviewed the manuscript and its scientific orientation. IMKN designed the study, reviewed the survey methodology, and reviewed the manuscript as well as its scientific orientation. All authors read and approved the final manuscript.

\section{ACKNOWLEDGMENTS}

This work was performed within the framework of a $\mathrm{PhD}$ project carried out in the laboratory of Environmental Biotechnologies of the Faculty of Science at the University of Yaounde I (Cameroon) in cooperation with the Institute for Hygiene and Public Health of the University of Bonn (Germany), supported by the German Academic Exchange Service (DAAD). The authors gratefully acknowledge the support of the field staff and data entry team of the University of Yaounde I, Dr. Silvia Schäffer and M.Sc. Valentina Grossi of the University of Bonn for the correction of the draft.

\section{REFERENCES}

Aryal KK, Joshi HD, Dhimal M, Singh SP, Dhimal B, Dhakal P, Bhusal CL. 2012. Environmental burden of diarrhoeal diseases due to unsafe water supply and poor sanitation coverage in Nepal. $J$. Nepal Health Res. Counc. 17 p.

Bakare BF, Brouckaert CJ, Foxon KM, Buckley CA. 2015. An investigation of the effect of pit latrine additives on VIP latrine sludge content under laboratory and field trials. Water SA, 41: 509-514.

Bakare BF, Foxon KM, Brouckaert CJ, Buckley CA. 2012. Variation in VIP latrine sludge contents. Water SA, 38: 479-486.

Barlett JE, Kotrlik JW, Higgins CC. 2001. Organizational research: Determining appropriate sample size in survey research. Inf. Technol. Learn. Perform. J., 19: 43.

Bartram J, Cairncross S. 2010. Hygiene, sanitation, and water: forgotten foundations of health. PLoS Med, 7: e1000367.

Berteigne. 2012. Quantification and characterization of faecal sludge in the city of Yaounde and Douala (Cameroon) (Master thesis). National School of Engineers of Water and Environment, Strasbourg, France. 112 p.

Brown J, Cumming O, Bartram J, Cairncross S, Ensink J, Holcomb D, Knee J, Kolsky P, Liang K, Liang S. 2015. A controlled, before-and-after trial of an urban sanitation intervention to reduce enteric infections in children: research protocol for the Maputo Sanitation (MapSan) study, Mozambique. BMJ Open, 5: e008215.

BUCREP. 2012. Results of the general population census in Cameroon. Technical report of BUCREP. Available from: http://www.bucrep.cm. $36 \mathrm{p}$.

Cairncross S, Bartram J, Cumming O, Brocklehurst C. 2010. Hygiene, 
sanitation, and water: what needs to be done? PLoS Med., 7: 1366.

Carlton EJ, Liang S, McDowell JZ, Li H, Luo W, Remais JV. 2012. Regional disparities in the burden of disease attributable to unsafe water and poor sanitation in China. Bull. World Health Organ., 90: 578-587.

Cheng S, Li Z, Nazim Uddin SM, Mang H-P, Zhou X, Zhang J, Zheng L, Zhang L. 2018. Toilet revolution in China. Journal of Environmental Management, 216: 347-356.

Curtis V, Cairncross S, Yonli R. 2000. Review: Domestic hygiene and diarrhoea-pinpointing the problem. Trop. Med. Int. Health, 5: 22-32.

De Silva S, Gunawardena IPP, Galagedara LW. 2011. Practical issues of partial onsite sanitation systems: two case studies from Sri Lanka. Tropical Agricultural Research, 22(2): 144 - 153.

Doczi J, Dorr T, Mason N, Scott A. 2013. The post-2015 delivery of universal and sustainable access to infrastructure services.

Dodane P-H, Mbéguéré M, Sow O, Strande L. 2012. Capital and operating costs of fullscale faecal sludge management and wastewater treatment systems in Dakar, Senegal. Environ. Sci. Technol., 46: 3705-3711.

Feachem RG, Guy MW, Harrison S, Iwugo KO, Marshall T, Mbere N, Muller R, Wright AM. 1983. Excreta disposal facilities and intestinal parasitism in urban Africa: preliminary studies in Botswana, Ghana and Zambia. Trans. $R$. Soc. Trop. Med. Hyg., 77: 515-521.

Gning JB, Diop C, Dongo K, Koné D. 2017. Facteurs déterminants le tarif de la vidange mécanique des matières de boues d'assainissement à Dakar. Int. J. Biol. Chem. Sci., 11(1): 313-332.

Graf J, Kemka N, Niyitegeka D, Meierhofer R, Zebaze TSH. 2010. Health gains from solar water disinfection (SODIS): evaluation of a water quality intervention in Yaounde, Cameroon. J. Water Health, 8: 779-796.
Guiteras R, Levinsohn J, Mobarak AM. 2015. Encouraging sanitation investment in the developing world: A cluster-randomized trial. Science, 348: 903-906.

Jenkins MW, Cumming O, Scott B, Cairncross S. 2014. Beyond "improved" towards "safe and sustainable" urban sanitation: assessing the design, management and functionality of sanitation in poor communities of Dar es Salaam, Tanzania. J. Water Sanit. Hyg. Dev., $\quad 4: \quad 131 . \quad$ Doi: 10.2166/washdev.2013.180

Jeuland M, Kone D, Strauss M. 2004. Private Sector Management of Faecal Sludge: A Model for the Future? Focus Innov. Plan. Exp. Bamako Mali Swiss Fed. Inst. Environ. Sci. Technol. Eawag Department Water Sanit. Dev. Countries. Sandec.

Klingel F, Montangero A, Koné D, Strauss M. 2002. Faecal sludge management in developing countries. A planning manual. EAWAG SANDEC 1-5.

Kone M, Service E, Ouattara Y, Ouattara P, Bonou L, Joly P. 2016. Caractérisation des boues de vidange dépotées sur les lits de séchage de zagtouli (Ouagadougou). Int. J. Biol. Chem. Sci., 10(6): 27812795.

Letah Nzouebet WA, Kengne Noumsi IM, Rechenburg A. 2016. Prevalence and diversity of intestinal helminth eggs in pit latrine sludge of a tropical urban area. J. Water Sanit. Hyg. Dev., 6: 622-630.

Lienou G, Mahe G, Paturel JE, Servat E, Sighomnou D, Ekodeck GE, Dezetter A, Dieulin C. 2008. Evolution des régimes hydrologiques en région équatoriale camerounaise: un impact de la variabilité climatique en Afrique équatoriale? Hydrol. Sci. J., 53: 789-801.

Lüthi C, Parkinson J. 2011. Environmental sanitation planning for cities of the South: linking local level initiatives with city-wide action, in: 35th WEDC International Conference: The Future of Water, Sanitation and Hygiene: Innovation, Adaptation and Engagement in a Changing World. $8 \mathrm{p}$. 
Mara D, Lane J, Scott B, Trouba D. 2010. Sanitation and health. PLoS Med., 7: 1359.

Matthew CF, Joshua VG, Gloria DS, Sophie B, Kate M, Kelly TA, Gauthami P, Darcy A, Amrita G, Jack ETG, Eva AR, Thomas FC. 2017. The impact of sanitation on infectious disease and nutritional status: A systematic review and meta-analysis. Int. J. Hyg. Environ. Health, 220: 928-949.

Ngoutane Pare M-M, Dongo K, Kengne IM, Dodane P-H, Akoa A, Kone D. 2012. The economic potential of Echinochloa pyramidalis (Lam.) Hitchc \& Chase forage plant used in liquid waste treatment in Cameroon: opportunity to link sanitation to food security. Int. J. Biol. Chem. Sci., 6(1): 210-236.

Niwagaba CB, Mbéguéré M, Strande L. 2014. Faecal Sludge Quantification, Characterisation and Treatment Objectives. Faecal Sludge Manag. Syst. Approach Implement. Oper., 19.

Parrot L, Sotamenou J, Dia BK. 2009. Municipal solid waste management in Africa: Strategies and livelihoods in Yaoundé, Cameroon. Waste Manag., 29: 986-995.

Pujari PR, Padmakar C, Labhasetwar PK, Mahore P, Ganguly AK. 2012. Assessment of the impact of on-site sanitation systems on groundwater pollution in two diverse geological settings - a case study from India. Environ. Monit. Assess., 184 : 251-263.

Soh Kengne E, Kengne IM, Nguetsop VF, Foubi SI, Akoa A, Strande L. 2014. Algal diversity and distribution in waste stabilization ponds treating faecal sludge leachate from drying vegetated beds. Int. J. Biol. Chem. Sci., 8(3): 946-955.
Stenström TA, Seidu R, Ekane N, Zurbrügg C. 2011. Microbial Exposure and Health Assessments in Sanitation Technologies and Systems. Stockholm Environment Institute: Stockholm, Sweden; $165 \mathrm{p}$.

Strande L, Ronteltap M, Brdjanovic D. 2014. Faecal Sludge Management: Systems Approach for Implementation and Operation. IWA Publishing; 403 p.

Taweesan A, Koottatep T, Polprasert C. 2015. Effective Faecal Sludge Management Measures for on-site Sanitation Systems. IWA publishing; $11 \mathrm{p}$.

Tilley E, Ulrich L, Lüthi C, Reymond P, Zurbrügg C. 2014. Compendium of Sanitation Systems and Technologies. Eawag; $158 \mathrm{p}$.

Tumwebaze IK, Orach CG, Niwagaba C, Luthi C, Mosler H-J. 2013. Sanitation facilities in Kampala slums, Uganda: users' satisfaction and determinant factors. Int. J. Environ. Health Res., 23: 191-204.

Verbyla ME, Oakley SM, Mihelcic JR. 2013. Wastewater infrastructure for small cities in an urbanizing world: integrating protection of human health and the environment with resource recovery and food security. Environ. Sci. Technol., 47: 3598-3605.

Wolf, Hunter PR, Matthew C F, Cumming O, Clasen T, Bartram J, Higgins JPT, Johnston R, Kate M, Sophie B, Prüss Ustün A. 2018. Impact of Drinking Water, Sanitation and Hand Washing with Soap on Childhood Diarrhoeal Disease: Updated Meta-Analysis and Meta-Regression. Tropical Medicine and International Health, 23(5): 508-525. Doi: 10.1111/tmi.13051. 